\title{
Anticoagulation by Ancrod for Haemodialysis
}

G. H. HALL, ${ }^{*}$ M.D., B.SC., M.R.C.P. ; HAZEL M. HOLMAN,† M.B., D.C.H., D.A. ; A. D. B. WEBSTER, $\ddagger$ M.B., M.R.C.P.

Cummary: The defibrinating agent ancrod (Arvin) $\checkmark$ was used instead of heparin for intermittent haemodialysis. It was an effective, and apparently safe, anticoagulant and reduced the deposition of fibrin and leucocytes on the Cellophane membrane. Administration was more complicated and urea dialysance was less with ancrod than with heparin.

\section{Introduction}

An essential condition for successful haemodialysis is the maintenance of an adequate blood flow through the dialyser. With the Kiil system the blood comes into contact with the polyvinyl chloride tubing and cuprophane or Cellophane membranes. Without prior anticoagulation blood would clot within this system. At present the accepted method of anticoagulation is to use heparin, either by constant infusion or by intermittent administration. Heparin is a relatively safe drug and its effect is easily reversed. Complications include spontaneous haemorrhage, hypersensitivity, alopecia, and more rarely osteoporosis (Griffith, Nichols, Asher, and Flanagan, 1965). Ancrod (Arvin) is prepared from the venom of the Malayan pit viper and produces its anticoagulant effect by defibrination (Reid, Thean, Chan, and Baharom, 1963).

After our experience with ancrod in other clinical contexts we wished to explore its.use in haemodialysis. The following questions were considered: (1) is ancrod an effective anticoagulant for haemodialysis? (2) what effect does it have on dialysance? (3) is fibrin and leucocyte deposition on the membrane affected? (4) what untoward side effects occur? and (5) can the anticoagulant schedule be simplified by its use in place of heparin?

\section{Patients and Methods}

The effects of heparin and ancrod were compared in four patients. Case 1: a man aged 22 with chronic nephritis; on haemodialysis for 30 months; anuric. Case 2: a man aged 35 with chronic nephritis; on haemodialysis for 20 months; unsuccessful cadaver allograft six months previously. Case 3: a man aged 49 with polycystic kidneys; on haemodialysis for 12 months. Case 4 : a man aged 48 with polycystic kidneys; on haemodialysis for six months; later (three months after trial) died of subarachnoid haemorrhage.

Anticoagulation with heparin was effected by a continuous infusion into the arterial line of the dialyser by roller pump; the total dose in 12 hours averaged 35,000 units.

Anticoagulation (defibrination) by ancrod was performed by the modified method described by Bell, Pitney, and Goodwin (1968). Initially ancrod (one unit per kilogram body weight) in $300 \mathrm{ml}$. of normal saline was given slowly over three hours via the patient's Silastic A-V shunt. If the fibrinogen level was then more than $10 \mathrm{mg} . / 100 \mathrm{ml}$. and the titre above one in four dilution a second similar dose in $20 \mathrm{ml}$. of normal saline was given by the same route over 15 minutes, followed by a further half dose if required (Table I). Dialysis was then begun, with no alteration in the usual routine apart from the absence of heparin. At the end of dialysis, which usually took place overnight and lasted about 12 hours, the patient was allowed

\footnotetext{
* Consultant Physician.

† Registrar in Pathology.
}

Medical Registrar.

Royal Devon and Exeter Hospital, Exeter EX1 1 PO.
TABLe I.-Anticoagulation Schedules of Two Patients Undergoing Haemodialysis using Heparin and Ancrod

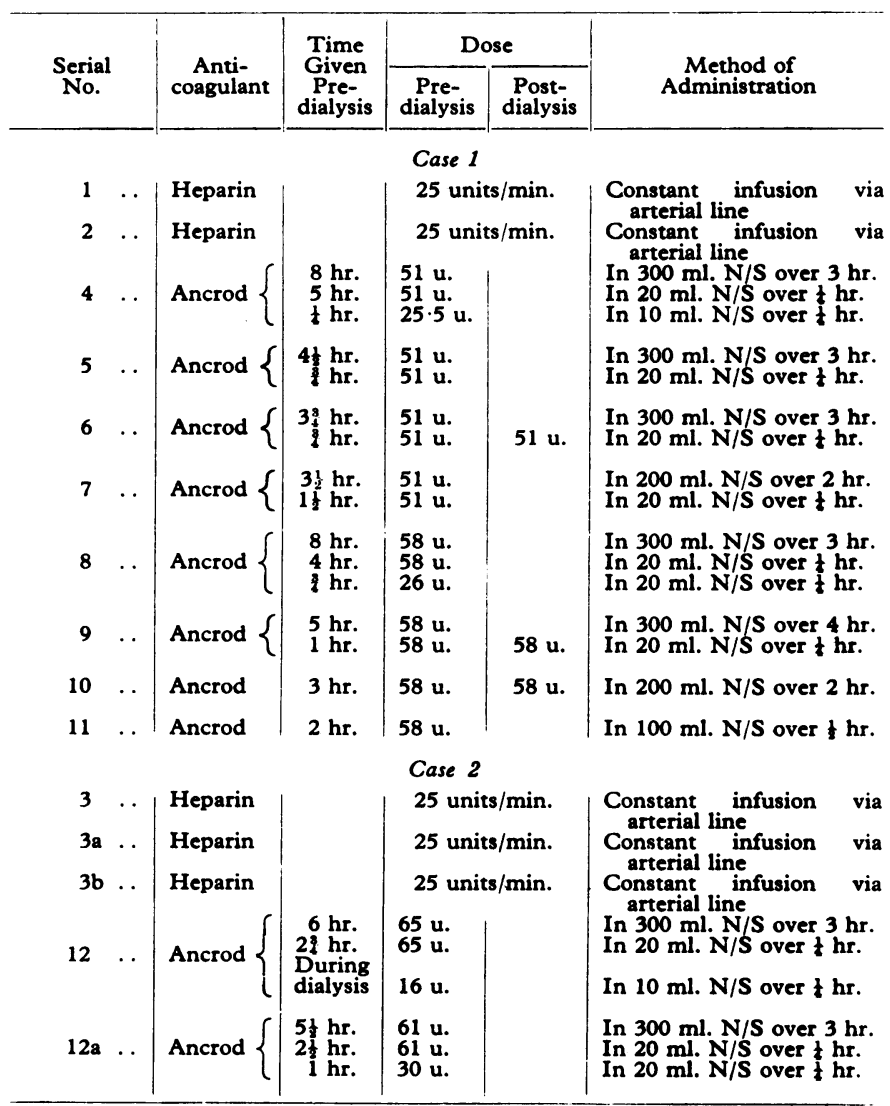

$\mathbf{N} / \mathbf{S}=$ Normal saline

home. He returned twice weekly for this regimen. Before subsequent dialyses we found that the pre-ancrod fibrinogen level was still below normal (Fig. 1). We then tried the effect of giving a dose of ancrod ( 1 unit per kg.) on some occasions before the patient went home, but found that there was no further reduction in the fibrinogen level on his return. Subsequently we shortened predialysis defibrination time to two

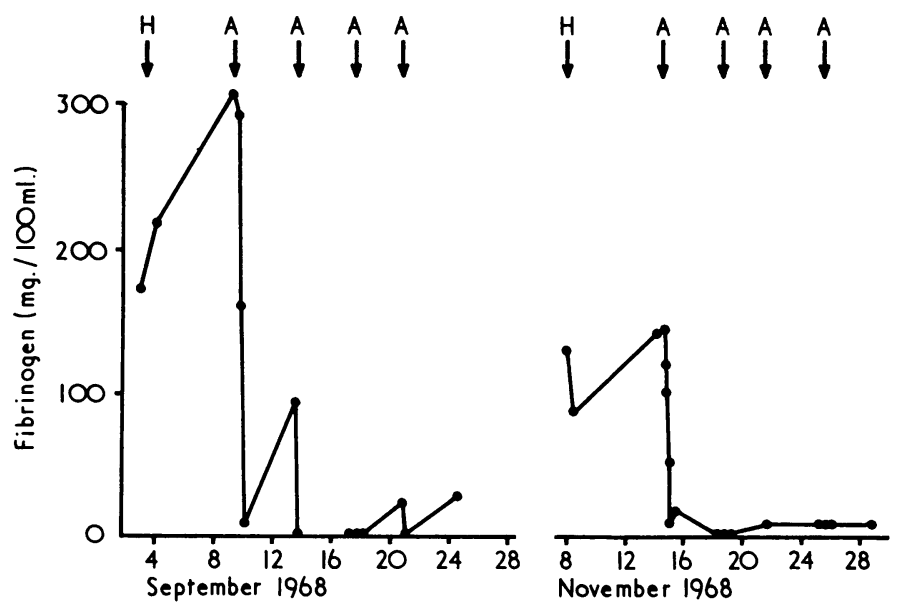

Frg. 1.-Fibrinogen levels during two trials of ancrod on Case 1. $\mathbf{H}=$ Heparin. $\mathbf{A}=$ Ancrod 
hours, and this could, if necessary, be shortened still further to about one hour (A. P. Fletcher, 1968, personal communication).

The fibrinogen level was estimated by the method of Stirland (1956), modified by R. D. Eastham (personal communication, 1961). The fibrinogen titre was estimated by the method of Sharp, Warren, Paxton, and Allington (1968). The order of treatment is shown in Table II. Blood flow was kept

TABLE II.-Urea Clearance Values During Dialysis. Number of Estimations Per Dialysis In Parentheses

\begin{tabular}{|c|c|c|c|c|}
\hline \multirow{2}{*}{ Case No. } & & & \multicolumn{2}{|c|}{ Urea Clearance $(\mathrm{ml} . / \mathrm{min}$. } \\
\hline & & & Heparin & Ancrod \\
\hline 2 & . & $\ldots$ & $\begin{array}{l}84(10) \\
86(10) \\
90(10)\end{array}$ & $81(8)$ \\
\hline 1 & .. & . & $\begin{array}{r}86(10) \\
110(9)\end{array}$ & $\begin{array}{l}80(6) \\
44(8) \\
41(7) \\
43(6)\end{array}$ \\
\hline 3. & $\ldots$ & .. & $\begin{array}{ll}72 & (4) \\
80 & (5) \\
80 & (5) \\
& \\
76 & (6) \\
76 & (6) \\
\end{array}$ & $\begin{array}{l}50(6) \\
78(2)\end{array}$ \\
\hline 4. &.. & . & $\begin{array}{rr}67 & (5) \\
120 & (5) \\
65 & (5) \\
& \\
110 & (5)\end{array}$ & $\begin{array}{l}74(7) \\
43(2) \\
75(3) \\
70(7)\end{array}$ \\
\hline
\end{tabular}

Mean urea clearances: Heparin $86 \mathrm{ml} . / \mathrm{min} .$, Ancrod, $62 \mathrm{ml} . / \mathrm{min} .(P<0.01)$.

as constant as possible by the use of a Watson-Marlow MHRE roller pump at about $120 \mathrm{ml}$./min. When heparin was used after ancrod refibrination of the patient was achieved by giving antivenom (130 units) and fibrinogen ( $1.5 \mathrm{~g}$.) intravenously.

Samples of arterial and venous blood were taken at intervals during dialysis. At the same time as the sampling, the blood flow was estimated by the bubble technique. Urea clearances were then calculated by the formula:

$\begin{gathered}\text { Urea clearance } \\ (\text { in } \mathrm{ml} . / \mathrm{min} .)\end{gathered}=\frac{\begin{array}{c}\text { Arterio-venous difference in urea } \\ \text { concentration }(\mathrm{mg} . / 100 \mathrm{ml} .)\end{array} \times \text { Blood flow in } \mathrm{ml} . / \mathrm{min} .}{\frac{1}{2} \text { (Arterial concentration }+ \text { venous concentration }}$

This formula for clearance was deliberately chosen as it reflects more closely the actual composition of the blood in the dialyser rather than the arterial blood; that is why we chose to use the mean of the arterial and venous levels.

Comparison of the effects of ancrod and heparin on white cell adherence to the cuprophane membranes was done by three methods. (1) Squares of membrane with sides measuring about $1.5 \mathrm{~cm}$. were cut, stained with haematoxylin and eosin, mounted on slides flat and in cross-section, and examined under the microscope. (2) A complete width of membrane $1 \mathrm{~cm}$. wide was coiled up from the broad end, stained with haematoxylin and eosin, and then sectioned in three places along the membrane. The number of nucleated cells per highpower field was counted along four radii at right angles to each other. (3) Elution method : A roll of membrane measuring about 40 by $3.5 \mathrm{~cm}$. was placed in $20 \mathrm{ml}$. of normal saline, and 6,000 i.u. of streptokinase added. It was shaken well, and incubated at $37^{\circ} \mathrm{C}$. for 10 minutes. Saponin, $0.1 \mathrm{mg}$., was then added to haemolyse the red cells, and the number of white cells were counted, using a particle counter.

\section{Results}

No dialysis had to be discontinued because of clotting in the dialyser, and at no time during defibrination did these patients experience haemorrhagic effects. In particular, there were no episodes of spontaneous bruising or nose-bleeds. One patient (Case 2), three hours after beginning the first dialysis after defibrination, complained of cramp in the leg containing the shunt. Though the fibrinogen reading was less than $10 \mathrm{mg} . / 100 \mathrm{ml}$., micro-clots were seen in the polyvinyl chloride tubing. A further quarter dose of ancrod (16 units) was given. The micro-clots disappeared but the leg remained painful, so dialysis was discontinued one hour later. There were no untoward after-effects, and the same shunt was used again for further dialysis.

No significant changes in fibrinogen concentration or titre were observed when using heparin. After the administration of ancrod the fibrinogen concentrations were reduced to less than $10 \mathrm{mg} . / 100 \mathrm{ml}$. and the fibrinogen titres from 0 to 1 in 4 (Fig. 2).
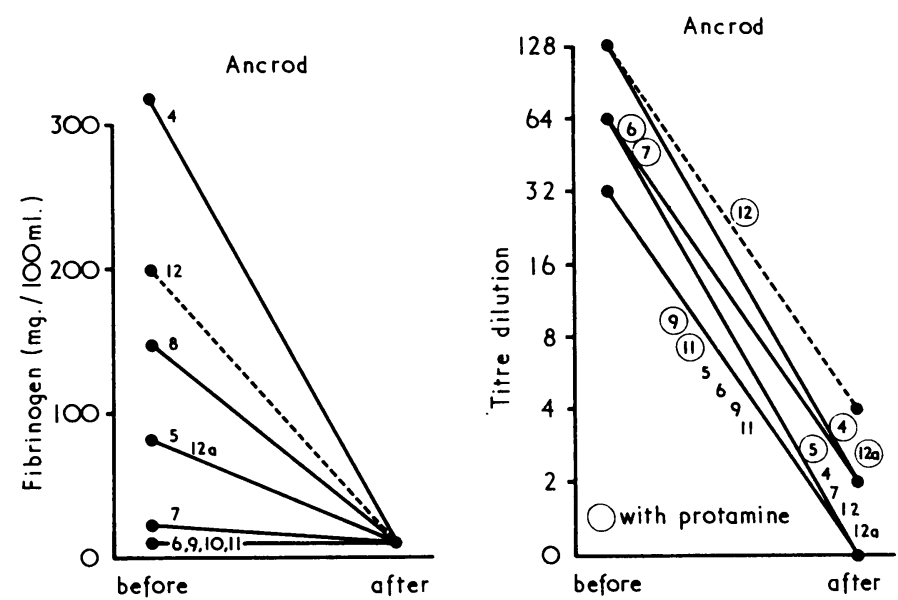

Fig. 2.-Effect of ancrod on fibrinogen concentration and titre. Continuous lines refer to Case 1, and dotted lines to Case 2. Numbers by lines refer to serial numbers of dialysis.

Urea dialysance values with ancrod were significantly less than those with heparin (Table II), according to Wilcoxon's sum of ranks test applied to the overall means of each dialysis (Langley, 1968). The average clearance with heparin was $86 \mathrm{ml}$. $/ \mathrm{min}$., and with ancrod $62 \mathrm{ml} . / \mathrm{min}(\mathrm{P}<0.01)$.

Pronounced differences in the degree of fibrin deposition and white cell adherence to the cuprophane membrane were observed. With method 1 , when using heparin the membrane was seen to be covered with fibrin and white cells (Figs. 3 and 4), but with ancrod the membrane appeared practically clear, except for the occasional clump of white cells in a platelet thrombus (Figs. 5 and 6). With method 2 three membranes were examined after heparin dialysis and four after ancrod. This method proved unreliable because of irregular clumping of cells.

With method 3 two membranes were examined after heparin and two after ancrod dialysis:

$$
\begin{aligned}
\text { Heparin (1) } & : 4.7 \text { million nucleated cells per roll } \\
\text { Heparin (2) } & : 3.4 \text { million nucleated cells per roll } \\
\text { Ancrod (1) } & : 1.64 \text { million nucleated cells per roll } \\
\text { Ancrod (2) } & 0.28 \text { million nucleated cells per roll }
\end{aligned}
$$

No significant alterations in haemoglobin concentrations, white cell and platelet count, serum bilirubin, alkaline phosphatase, aspartate aminotransferase, and lactic acid dehydrogenase levels were observed. Heparin had no effect on the erythrocyte sedimentation rate (E.S.R.). A reduction of about $30 \%$ in the E.S.R. was observed after ancrod, presumably due to removal of the plasma fibrinogen. 


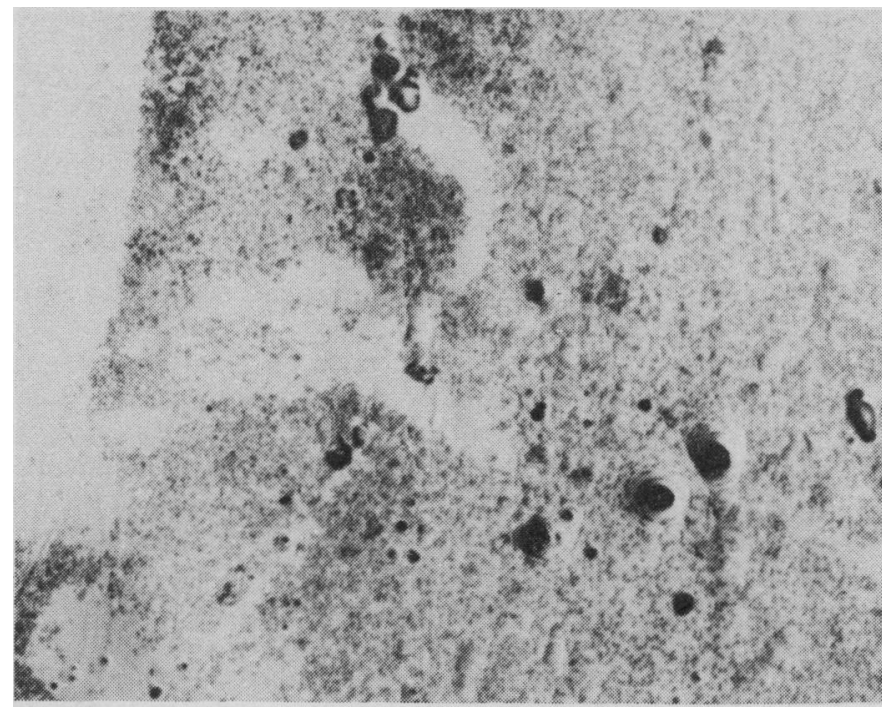

Fig. 3.-Plan view of cuprophane membrane at end of dialysis using heparin as anticoagulant, showing numerous adherent cells (mainly polymorphs). (H. \& E. $\times 35$ ).

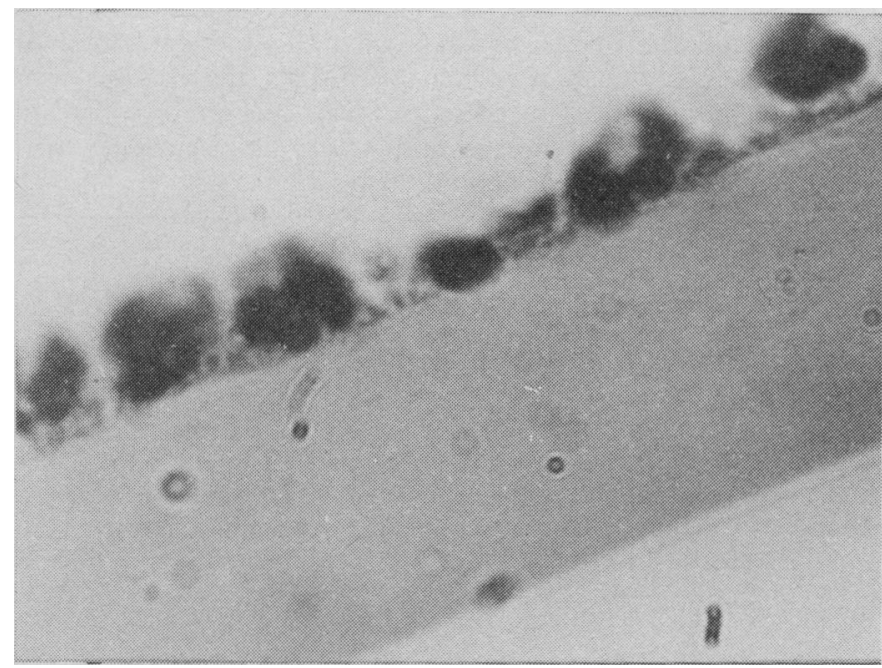

FIG. 4.-Section of cuprophane membrane, after heparin, showing polymorphs adherent to surface. (H. \& E. $\times 2,100)$.

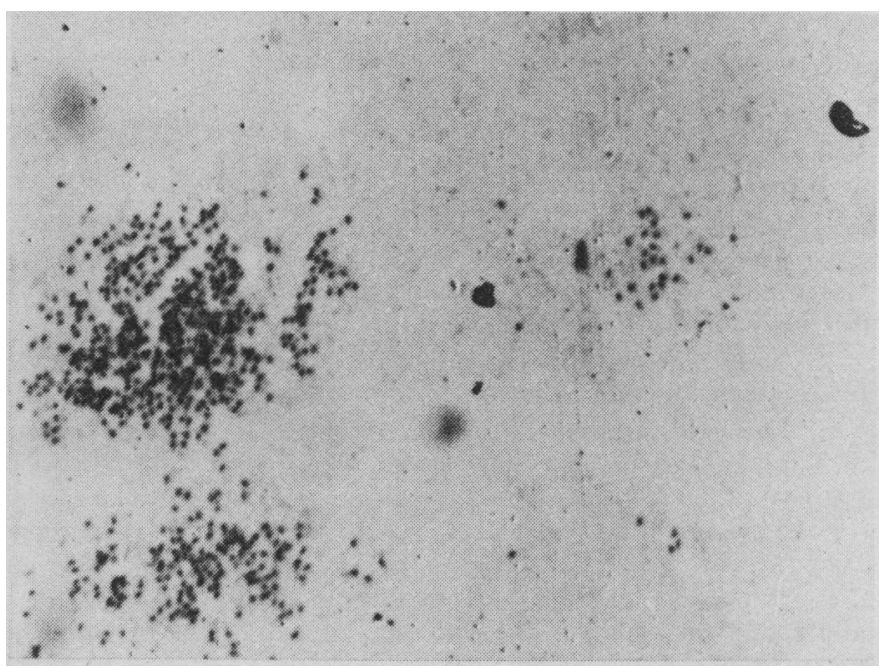

FIG. 5.-Plan view of cuprophane membrane after dialysis using ancrod, showing isolated clumps of adherent cells (H. \& E. , 40).

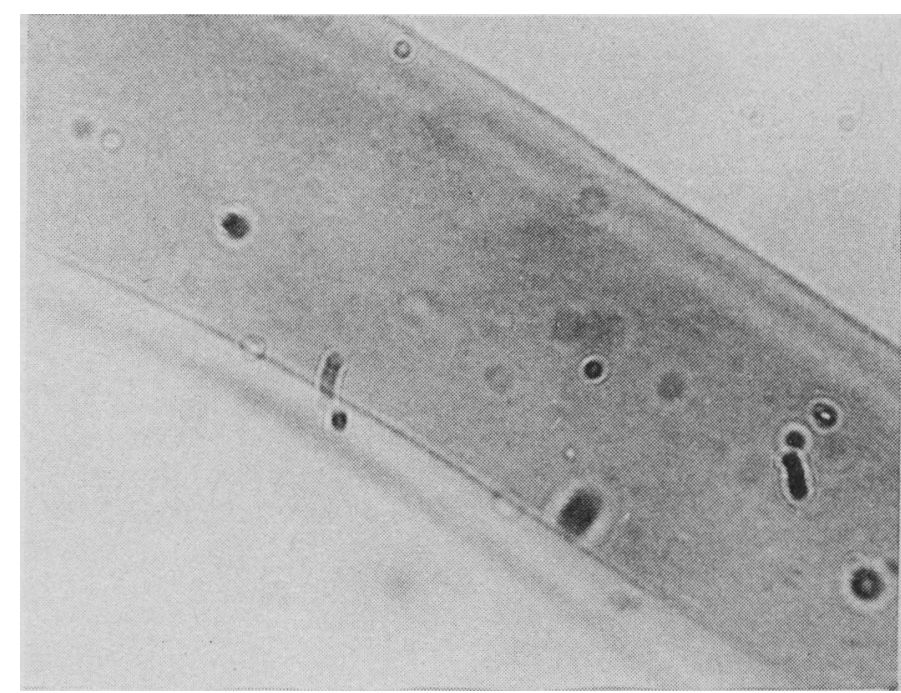

FIc. 6.-Section of cuprophane membrane after dialysis using ancrod, showing absence of adherent polym :rphs. (H. \& E. $\times 3,360)$.

\section{Discussion}

Ancrod is an effective anticoagulant for haemodialysis, but the procedure involved in initiating and maintaining defibrination is more complicated than administering heparin by constant infusion. With twice-weekly dialyses doses of ancrod are needed before each procedure. Even with thrice-weekly dialyses it is unlikely that these doses could be omitted or given in conjunction with dialysis, as in the case of heparin.

The effects of long-term defibrination are not known, but there is no evidence at present to suggest that complications will occur. One must consider, however, that accidental trauma could cause catastrophic bleeding.

Urea dialysance appears to be less when using ancrod than when using heparin. The reasons for this are as yet unexplained. It could be argued that the fibrin which collects on the membrane during dialysis with heparin might obstruct the micropores in the membrane and thereby reduce dialysing efficiency. Our findings do not support this concept. On the other hand, the presence of fibrin may produce local turbulence which could benefit dialysis (Treybal, 1955).

In view of our findings we would not at this stage recommend the use of ancrod as an alternative to heparin in haemodialysis.

The Arvin was generously provided by the courtesy of Twyford Laboratories Limited. This work could not have been accomplished without the help of Dr. J. O. P. Edgcumbe, Dr. D. Spencer, Mr. P. Jones, Mr. R. Perry, the staff of the department of pathology, and the nursing and technical staff of the artificial kidney unit, Exeter.

\section{REFERENCES}

Bell, W. R., Pitney, W. R., and Goodwin, J. F. (1968). Lancet, 1, 490.

Griffith, G. C., Nichols, G. Asher, J. D., and Flanagan, B. (1965). Journal of the American Medical Association, 193, 91.

Langley, R. (1968). Practical Statistics for Non-Mathematical People, p. 168. London, Pan.

Reid, H. A., Thean, P. C., Chan, K. E., and Baharom, A. R. (1963). Lancet, Sharp, A. A., Warren, B. A., Paxton, A. M., and Allington, M. J. (1968). Lancet, 1, 493.

Stirland, R. M. (1956). Lancet, 1, 672.

Treybal, R. E. (1955). Mass-transfer Operations. New York, McGraw-Hill. 